ISSN : 1412-7601

Volume 3, No.2 September 2017

http://www.ekonobis.unram.ac.id

EKONOBIS

\title{
Marketing Strategy Pariwisata Melalui Marketing Mix Strategy Dan Pengembangan Pariwisata di Kabupaten Lombok Utara (KLU)
}

\author{
Irwan Suriadi, Didy Ika Supryadi
}

Universitas Mataram

\begin{tabular}{l}
\hline A R T I C L E I N F O \\
\hline Keywords: \\
MarketingStrategy, Marketing \\
Mix, SWOT Analisys, North \\
Lombok district (KLU)
\end{tabular}

Received : 30 Juli 2017; Accepted: 27 Agustus 2017; Published: September 2017

ABSTRACT : This study entitled "Marketing Strategy Through Tourism Marketing Mix

Strategy and the development of tourism in north Lombok district (KLU)". The problems of this study were (a) How is the marketing mix of tourism in north Lombok district (KLU) (b) What factors are the strengths, weaknesses, threats and opportunities of tourism development in north Lombok district (KLU), (c) how is the development of tourism in north Lombok district (KLU), the aim of this study is (a) To analyze how the marketing mix of tourism in Lombok district to the north. (b) what factors are the strengths, weaknesses, threats and opportunities for tourism development in North Lombok regency (c) To formulate tourism development strategy in North Lombok regency. This research is a qualitative research and strategy trying to find a picture pemasarn appropriate tourism in north Lombok district (KLU). The analysis method used in this research is descriptive analysis and SWOT Analisys. The results showed that factors internal strategy (force) that has the main force is the uniqueness in the sights, factors internal strategy (weakness) that has a weakness is the main factor Palayanan to tourists in tourist areas, Opportunity's premier tourist $\mathrm{KLU}$ is the layout of the area attractions are located, factor strategy External (threats) which has a main threat is competition tourism intensifies, strategy of tourism development in the KLU is the tourism office at north Lombok district (KLU) must often hold iven-iven tourism in north Lombok district (KLU) and follow ivent sale inside and outside the country.

Kata Kunci :

MarketingStrategy, Marketing

Mix, SWOT Analisys,

Kabupaten Lombok Utara
ABSTRAK : Penelitian ini berjudul "Marketing Strategy Pariwisata Melalui Marketing Mix Strategy dan pengembangan Pariwisata di Kabupaten Lombok Utara (KLU)". Rumusan masalah dalam penelitian ini adalah (a) Bagaimana strategi bauran pemasaran pariwisata di Kabupaten Lombok Utara (KLU) (b) Faktor-faktor apa saja yang menjadi kekuatan,kelemahan,ancaman dan peluang pengembangan pariwisata di Kabupaten Lombok Utara (KLU), (c)Bagaimana pengembangan pariwisata di Kabupaten Lombok Utara (KLU),Tujuan penelitian ini adalah (a) Untuk Menganalisis bagaimana strategi bauran pemasaran pariwisata di kabupaten Lombok utara.(b)Faktor-faktor apa saja yang menjadi kekuatan,kelemahan,ancaman dan peluang pengembangan pariwisata di kabupaten Lombok Utara (c) Untuk merumuskan strategi pengembangan pariwisata di Kabupaten Lombok Utara. Jenis penelitian ini adalah penelitian kualitatif yang mencoba mencari gambaran dan strategi pemasarn pariwisata yang sesuai di kabupaten Lombok utara (KLU). Metode Analisis yang digunakan dalam penelitian ini adalah Analisis Deskriptif dan SWOT Analisys. Hasil penelitian menunjukkan bahwa Faktor strategi internal (kekuatan) yang memiliki kekuatan utama adalah Keunikan di tempat wisata, Faktor strategi internal (Kelemahan) yang memiliki kelemahan yang utama adalah Faktor Palayanan kepada wisatawan di kawasan wisata, Peluang utama pariwisata KLU adalah Letak daerah wisata yang strategis, Faktor strategi Eksternal (Ancaman) yang memiliki ancaman utama adalah Persaingan pariwisata yang semakin ketat, Strategi pengembangan pariwisata di KLU adalah Dinas pariwisata kabupaten Lombok utara (KLU) harus sering mengadakan iven-iven pariwisata di kabupaten Lombok utara (KLU) dan mengikuti ivent promosi di dalam dan diluar negeri.

Corresponding Author:

Alamat: Program Studi Ekonomi Pembangunan, Fakultas Ekonomi dan Bisnis, Universitas Mataram, Jln. Majapahit No. 62 Mataram.

e-mail: irwansuriadi@unram.ac.id 


\section{PENDAHULUAN}

\section{Latar Belakang}

Sektor pariwisata sangat penting dikembangkan karena memiliki peranan yang sangat penting dalam perekonomian, dimana pada tahun 2007 sumbangannya terhadap Produk Domestik Bruto (PDB) cukup besar yang mencapai $3,7 \%$, sumbangan yang cukup besar ini harus diimbangi oleh pemerintah melalui kebijakan kepariwisataan yang sesuai dengan kebutuhan sektor pariwisata saat ini, karena dunia pariwisata saat ini sangat cepat berubah terutama yang berkaitan dengan wisatawan asing karena memiliki perilaku yang cukup dinamis dalam memilih atau mencari daerah wisata yang akan dikunjunginya. Pengembangan pariwisata harus memiliki sinergitas antara kebijakan pemerintah pusat dengan kebijakan pemerintah daerah (Pemda) agar seluruh program pengembangan pariwisata tersebut dapat tercapai dengan baik.

Suatu Kebijakan pengembangan pariwisata oleh pemerintah pusat maupun daerah (PEMDA) terlihat dari jumlah kunjungan wisatawan, baik wisatawan domestic (lokal dan nasional) maupun wisatawan asing (Luar Negeri), semakin banyak jumlah kunjungan wisatawan kesuatu daerah wisata maka semakin baik juga pengembangan pariwisata oleh pemerintah daerah dan sebaliknya semakin berkurang jumlah kunjungan wisatawan kesuatu daerah maka kebijakan pengembangan pariwisatanya semakin tidak baik, oleh karena itu jumlah kunjungan wisatawan menjadi kunci keberhasilan kebijakan pemerintah pada sektor pariwisata.

Pengembangan sektor pariwisata dilakukan juga oleh Pemerintah kabupaten Lombok utara (KLU) yang menjadikan pariwisata sebagai sektor unggulan karena potensi wisata yang dimiliki oleh kabupaten Lombok utara cukup banyak dan memiliki potensi yang cukup besar yang terlihat pada tabel 1.1 dibawah ini.

Tabel 1 Nama dan jenis beberapa objek wisata di kabupaten Lombok utara (KLU) Tahun 2013

\begin{tabular}{|c|c|c|}
\hline Kecamatan & Nama objek wisata & Jenis objek wisata \\
\hline 1.Pemenang & $\begin{array}{l}\text { a. Gili Tramena (Trawangan, Meno, Air) } \\
\text { b. Goa Jepang Gili Trawangan } \\
\text { c. Hutan Wisata Pusuk } \\
\text { d. Pantai Malimbu } \\
\text { e. Teluk Nara }\end{array}$ & $\begin{array}{l}\text { Alam/Pantai } \\
\text { Alam/Sejarah } \\
\text { Alam/Hutan } \\
\text { Alam/Pantai } \\
\text { Alam/Pantai }\end{array}$ \\
\hline 2.Tanjung & $\begin{array}{l}\text { a. Pantai Sire } \\
\text { b. Arung Jeram Tengak Pekatan }\end{array}$ & $\begin{array}{l}\text { Alam/Pantai } \\
\text { Minat Khusus }\end{array}$ \\
\hline 3.Gangga & $\begin{array}{l}\text { a. Pantai Kerakas } \\
\text { b. Dusun Selelos Budaya } \\
\text { c. Air Terjun Kerta Raharja } \\
\text { d. Air Terjun Tiu Pupus } \\
\text { e. Pantai Lempenge } \\
\text { f. Pantai Montong Pal }\end{array}$ & $\begin{array}{l}\text { Alam/Pantai } \\
\text { Budaya } \\
\text { Alam/Pegunungan } \\
\text { Alam/Pegunungan } \\
\text { Alam/Pantai } \\
\text { Alam/Pantai }\end{array}$ \\
\hline 4.Kayangan & $\begin{array}{l}\text { a. Air Terjun Tiu Teja } \\
\text { b. Air Terjun Sesait } \\
\text { c. Masjid Kuno Sesait }\end{array}$ & $\begin{array}{l}\text { Alam/Pegunungan } \\
\text { Alam/Pegunungan } \\
\text { Budaya }\end{array}$ \\
\hline 5.Bayan & $\begin{array}{l}\text { a. Air Terjun Sindang Gila } \\
\text { b. Air Terjun Tiu Kelep } \\
\text { c. Air Terjun Torean } \\
\text { d. Masjid Kuno Bayan Beleq } \\
\text { e. Desa Tradisional Senaru } \\
\text { f. Desa Tradisional Segenter } \\
\text { g. Taman Nasional Gunung Rinjani } \\
\text { h. Pantai Tanjung Menangis }\end{array}$ & $\begin{array}{l}\text { Alam/Pegunungan } \\
\text { Alam/Pegunungan } \\
\text { Alam/Pegunungan } \\
\text { Budaya } \\
\text { Budaya } \\
\text { Budaya } \\
\text { Alam/Pegunungan } \\
\text { Alam/Pantai }\end{array}$ \\
\hline
\end{tabular}


Dari tabel 1 diatas tersebut terlihat bahwa cukup banyak potensi pariwisata yang dimiliki oleh kabupaten Lombok utara, terutama wisata pantai yang cukup terkenal dikalangan wisatawan seperti tiga gili yang memiliki wisata pantai yang indah yaitu gili tramena (Trawangan, Meno, Air) yang terletak dikecamatan Pemenang, selain itu juga banyak juga potensi yang belum digarap secara maksimal oleh pemerintah daerah seperti objek wisata yang berada di wilayah kecamatan tanjung, gangga, kayangan dan bayan yang memiliki wisata alam, pantai, pegunungan,dan budaya. Potensi wisata yang cukup besar tersebut akan mendatangkan manfaat ekonomi bagi pemerintah maupun masyarakat sekitar. Agar dapat mendatangkan manfaat ekonomi maka perlu adanya perhatian dari pemerintah daerah dengan mengeluarkan kebijakan-kebijakan dalam mengembangkan potensi pariwisata di kabupaten Lombok utara, salah satu indikator keberhasilan dalam pariwisata adalah jumlah kunjungan wisatawan disuatu daerah.

Tabel 2 Jumlah kunjungan wisatawan di kabupaten Lombok utara

\begin{tabular}{|c|c|c|c|}
\hline Tahun & Wisatawan domestik & Wisatawan asing & Jumlah total \\
\hline 2010 & 39.094 & 191.673 & 230.767 \\
\hline 2011 & 31.511 & 306.135 & 337.646 \\
\hline 2012 & 43.165 & 383.804 & 426.969 \\
\hline
\end{tabular}

Sumber : KLU dalam Angka 2013

Berdasarkan tabel 2 diatas terlihat bahwa jumlah kunjungan wisatawan di kabupaten Lombok utara mengalami kenaikan dimana pada tahun 2010 jumlah wisatawan asing maupun domestic berjumlah 230.767 orang sedangkan pada tahun 2012 jumlah kunjungan wisatawan asing maupun domestic berjumlah 426.969 orang, artinya kabupaten Lombok utara memiliki pariwisata yang disukai oleh para wisatawan asing maupun domestic atau menjadi tujuan utama bagi para wisatawan.

Untuk meningkatkan jumlah kunjungan wisatawan ke kabupaten Lombok utara maka perlu adanya strategi pemasaran yang tepat melalui bauran pemasaran pariwisata (product, price, place, promotion), oleh karena itu peneliti mengambil judul penelitian "Marketing Strategy Pariwisata Melalui Marketing Mix Strategy dan Pengembangan Pariwisata di Kabupaten Lombok Utara (KLU)"

\section{Perumusan Masalah}

Dari uraian di atas dapat diambil pokok permasalahannya yaitu:

1. Bagaimana strategi bauran pemasaran pariwisata di Kabupaten Lombok Utara (KLU)

2. Faktor-faktor apa saja yang menjadikekuatan,kelemahan, ancaman dan peluang pengembangan pariwisata di Kabupaten Lombok Utara (KLU)
3. Bagaimana pengembangan pariwisata di Kabupaten Lombok Utara (KLU)

\section{Tujuan Penelitian}

1. UntukMenganalisisbagaimana strategi bauran pemasaran pariwisata di kabupaten Lombok utara.

2. Faktor-faktor apa saja yang menjadikekuatan,kelemahan,ancaman dan peluang pengembangan pariwisata di kabupaten Lombok Utara

3. Untuk merumuskan strategi pengembangan pariwisata di Kabupaten Lombok Utara

\section{Manfaat penelitian}

1. Membantu dinas pariwisata kabupaten lombok utara dalam mengembangkan pariwisata di kabupaten lombok utara

2. Membantu pemerintah kabupaten Lombok utara dalam menerapkan strategi bauran pemasaran pariwisata di kabupaten Lombok utara

3. Secara teoritis sebagai tambahan refrensi bagi pihak-pihak yang ingin melakukan penelitian lebih lanjut berkaitan dengan pengembangan dan strategi bauran pemasaran di kabupaten Lombok

\section{Penelitian Terdahulu}

TINJAUAN PUSTAKA

Begum \& Sarker (2013) meneliti dengan judul "Marketing Strategies For Tourism 
Industry In Bangladesh: Emphasize On Niche Market Strategy For Attracting Foreign Tourists", permasalahan penelitiannya adalah Bangladesh memiliki prospek cerah pariwisata di masa depan. Dia memiliki potensi pariwisata di seluruh negara. Tapi, pariwisata Bangladesh menghadapi begitu banyak masalah termasuk strategi pemasaran. Hasil penelitiaannya menunjukkan bahwa bahwa empat produk ikonik dapat memainkan peran penting dalam total pendapatan di sektor ini. Akhirnya, tulisan ini menunjukkan bagaimana strategi ceruk pasar akan membantu pembuat kebijakan untuk membedakan pasar wisatawan dan menyesuaikan layanan mereka untuk mencapai tujuan pemasaran strategis dan memecahkan laba bawah ini..

Wu \& Zhang (2013) meneliti dengan judul penelitian Research on the Tourism Effect and Marketing Strategy of Convention \& Exposition Industry: A Case Study of Shenzhen City of China. Tujuan dari penelitian ini adalah untuk menganalisis secara teoritis pengaruh pariwisata dan strategi pemasaran dari C \& $E$ industri. Untuk melakukan penelitian ini, metode penelitian yang digunakan adalah deskriptif induktif dan teori dengan menganalisis penawaran dan permintaan pariwisata. Hasil penelitian menunjukkan tidak hanya dapat $C$ \& $E$ menghasilkan pengaruh positif seperti efek sinergis dan efek cluster pada pariwisata,tetapi juga hasil negatif yang ditandai dengan efek spillover dengan mengambil kota Shenzhen Cina sebagai contoh, beberapa strategi pemasaran yang ditemukan bahwa strategi tersebut pada C \& E dan kegiatan pameran acara dapat memenuhi kebutuhan Shenzhen akan pengunjung, dan meningkatkan citra tur kota ini, sehingga dapat membantu memperluas pengaruhnya pada pariwisata lainnya di Cina pada umumnya.

Gustavo, (2013) melakukan penelitian yang berjudul Marketing Management Trends in Tourism and Hospitalitylndustry: Facing the 21st Century Environment. Permasalahan dalam penelitian ini adalah Dinamika baru dari abad kedua puluh satu menyebabkan lingkungan yang kompetitif baru di bidang pariwisata dan bisnis perhotelan. Skenario ini mendorong perusahaan-perusahaan industri untuk mengadopsi pilihan baru pemasaran strategis dan proses pemasaran operasional. Tujuan Penelitian ini fokus pada pada perubahan besar pada tingkat lingkungan pariwisata dan perhotelan mikro, menguraikan perubahan utama dan tren permintaan. Alat analisis yang digunakan adalah analisis MATRIK. Hasil penelitian penunjukkan bahwa tren pada manajemen pemasaran strategis dan operasional dari pariwisata dan perhotelan sudah berkembang dengan sangat pesat dan diperlukan penyesuaian dalam menghadapi persaingan. Yaitu dengan memperhatikan lingkungan (makro dan mikro) dalam pariwisata.

Purnomo (2009) melakukan penelitian yang berjudul Strategi Pemasaran Produk Wisata Minat Khusus Goa Cerme, Imogiri, Bantul", tujuan penelitian ini adalah mengenali strategi pemasaran untuk pariwisata minat khusus produk dari Gua Cerme terletak di Kecamatan Imogiri, Kabupaten Bantul. Metode yang digunakan dalam penelitian adalah metode survey deskriptif. Data karakteristik pasar itu dikumpulkan dengan menyebarkan kuesioner, dan sampel ditentukan dengan menggunakan Metode purposive sampling. Data produk dikumpulkan dengan menggunakan observasi dan dokumentasi, maka kualitas produk dinilai menggunakan scoring terhadap tarik-akses-fasilitas. Hasil penelitiannya menunjukkan bahwa karakteristik pasar, pendidikan, suka melakukan petualangan, mengunjungi objek dalam kelompok, menghabiskan lebih sedikit uang dan berasal dari daerah yang dikelilingi. Kegiatan utama mereka menelusuri sepanjang gua dan melakukan relaksasi. Skor kualitas produk adalah 38 (kualitas tinggi) untuk daya tarik, 6 (kualitas medium) untuk akses dan 6 (kualitas rendah) untuk fasilitas. strategi yang direkomendasikan adalah diferensiasi produk dan diversifikasi, positioning antara produk-produk lainnya, harga yang efektif adalah tinggi-harga premium kualitas produk, dan kemitraan yang aktif semua pemangku kepentingan. Kemudian, pariwisata itu dikemas dengan menggabungkan daya tarik pertanian- 
pengamatan dan budaya gua, dengan promosi yang efektif kepada para calon wisatawan, oleh karena itu media yang efektif yang harus digunakan dalam promosi adalah internet.

Magatep (2015) melakukan penelitian yang berjudul "The Impact of Tourism Marketing Mix Elements on the Satisfaction of Inbound Tourists to Jordan". Tujuan penelitiannya adalah untuk mengetahui dampak pariwisata dan bauran pemasaran dan bagaimana hal itu mempengaruhi pariwisata di Yordania, untuk menentukan elemen dari bauran pemasaran memiliki dampak yang kuat pada pariwisata di Yordania dan bagaimana cara memuaskan wisatawan di Yordania. Responden yang diguanakan adalah wisatawan asing yang datang ke Yordania; metode penelitian yang digunakan adalah metode survei lapangan dengan menggunakan kuesioner untuk mengumpulkan data penelitian. Hasil penelitiannya menunjukkan bahwa semua bauran pemasaran terutama produk \& promosi memiliki pengaruh kuat terhadap kepuasan wisatawan asing, di mana harga dan distribusi juga memiliki pengaruh yang signifikan.Penelitian ini juga merekomendasikan strategi pemasaran yang sesuai untuk semua elemen terutama kebijakan bauran pemasaran produk \& promosi.

\section{Landasan Teori}

\section{Pariwisata \\ Definisi Pariwisata}

Menurut Undang-undang No. 10 Tahun 2009 tentang kepariwisataan, Pengertian pariwisata adalah berbagai macam kegiatan wisata dan didukung berbagai fasilitas serta layanan yang disediakan oleh masyarakat, pengusaha, pemerintah, dan pemerintah daerah.

Pengertian lain dari Pariwisata menyebutkan bahwa periwisata adalah suatu perjalanan yang dilakukan untuk sementara waktu, yang diselenggarakan dari suatu tempat lain, dengan maksud bukan untuk mencari nafkah di tempat yang dikunjungi, tetapi semata-mata untuk menikmati perjalanan hidup guna bertamasya dan berkreasi untuk memenuhi keinginan yang beraneka ragam (Yoeti,2006).

Sedangkan Marpaung (2002) mendifinisikan pariwisata sebagai perpindahan sementara yang dilakukan manusia dengan tujuan keluar dari pekerjaan-pekerjaan rutin, keluar dari tempat kediamannya. Aktivitas dilakukan selama mereka tinggal di tempat yang dituju dan fasilitas yang dibuat untuk memenuhi kebutuhan mereka.

Soekadijo (1997) mendifinisikan pariwisata sebagai segala kegiatan dalam masyarakat yang berhubungan dengan wisatawan. Semua kegiatan pembangunan hotel, pemugaran cagar budaya, pembuatan pusat rekreasi, penyelenggaraan pekan pariwisata, penyediaan angkutan dan sebagainya semua itu dapat disebut kegiatan pariwisata sepanjang dengan kegiatankegiatan itu semua dapat diharapkan para wisatawan akan datang.

Menurut World Tourism Organization (WTO) pariwisata adalah kegiatan seseorang yang bepergian ke atau tinggal di suatu tempat di luar lingkungannya yang biasa dalam waktu tidak lebih dari satu tahun secara terus menerus, untuk kesenangan, bisnis ataupun tujuan lainnya. (Pitana, 2009)

\section{Jenis-Jenis Pariwisata}

Menurut Pendit (1999) pariwisata dibagi menjadi beberapa jenis, antara lain: pariwisata menjadi beberapa jenis yaitu :

a. Wisata Industri, Perjalanan yang dilakukan oleh rombongan pelajar atau mahasiswa, atau orangorang awam ke suatu kompleks atau daerah perindustrian dimana terdapat pabrik-pabrik atau bengkel-bengkel besar dengan maksud tujuan untuk mengadakan peninjauan atau penelitian. Misalnya, rombongan pelajar yang mengunjungi industri tekstil.

b. Wisata Politik, Perjalanan yang dilakukan untuk mengunjungi atau mengambil bagian aktif dalam peristiwa kegiatan politik. Misalnya, ulang tahun 17 Agustus di Jakarta, Perayaan 10 Oktober di Moskow, 
Penobatan Ratu Inggris, Perayaan Kemerdekaan, Kongres atau konvensi politik yang disertai dengan darmawisata.

c. Wisata Konvensi,Perjalanan yang dilakukan untuk melakukan konvensi atau konferensi. Misalnya APEC, KTT non Blok.

d. Wisata Sosial, Merupakan pengorganisasian suatu perjalanan murah serta mudah untuk memberi kesempatan kepada golongan masyarakat ekonomi lemah untuk mengadakan perjalanan seperti kaum buruh, pemuda, pelajar atau mahasiswa, petani dan sebagainya.

e. Wisata Pertanian

Merupakanpengorganisasian perjalanan yang dilakukan ke proyek-proyek pertanian, perkebunan, ladang pembibitan dan sebagainya dimana wisatawan rombongan dapat mengadakan kunjungan dan peninjauan untuk tujuan studi maupun melihat-lihat keliling sambil menikmati segarnya tanaman beraneka ragam warna dan suburnya pembibitan di tempat yang dikunjunginya.

f. Wisata Budaya, Merupakan perjalanan wisata atas dasar keinginan untuk memperluas pandangan seseorang dengan mengadakan kunjungan atau peninjauan ke tempat lain atau ke luar negeri, mempelajari keadaan rakyat, kebiasaan dan adat istiadat mereka.

g. Wisata Kesehatan, Hal ini dimaksudkan dengan perjalanan seorang wisatawan dengan tujuan untuk menukar keadaan dan lingkungan tempat seharihari di mana ia tinggal demi kepentingan beristirahat baginya dalam arti jasmani dan rohani dengan mengunjungi tempat peristirahatan seperti mata air panas mengandung mineral yang dapat menyembuhkan, tempat yang memiliki iklim udara menyehatkan atau tempat yang memiliki fasilitasfasilitas kesehatan lainnya.

h. Wisata Olah Raga, Wisatawan yang melakukan perjalanan dengan tujuan berolahraga atau. memang sengaja bermaksud mengambil bagian aktif dalam peserta olahraga disuatu tempat atau Negara seperti Asian Games, Olympiade, Thomas Cup, Uber Cup dan lain-lain. Bisa saja olah raga memancing, berburu, berenang.

i. Wisata Komersial, Dalam jenis ini termasuk perjalanan untuk mengunjungi pameranpameran dan pekan raya yang bersifat komersial, seperti pameran industri, pameran dagang dan sebagainya.

j. Wisata Maritim (Marina) atau Bahari, Wisata yang dikaitkan dengan kegiatan olah raga di air, lebih-lebih danau, bengawan, teluk atau laut. Seperti memancing, berlayar, menyelam, berselancar, balapan mendayung dan lainnya.

k. Wisata Cagar Alam, Wisata ini biasanya diselenggarakan oleh agen atau biro perjalanan yang mengkhususkan usahausaha dengan jalan mengatur wisata ke tempat atau daerah cagar alam, tanaman lindung, hutan daerah pegunungan dan sebagainya.

I. Wisata Buru, Wisata untuk buru, ditempat atau hutan yang telah ditetapkan 
pemerintah Negara yang bersangkutan sebagai daerah perburuan, seperti di Baluran, Jawa Timur untuk menembak babi hutan atau banteng.

m. Wisata Pilgrim, Jenis wisata ini dikaitkan dengan agama, sejarah, adat-istiadat dan kepercayaan umat atau kelompok dalam masyarakat Ini banyak dilakukan oleh rombongan atau perorangan ketempat-tempat suci, ke makam-makam orang besar, bukit atau gunung yang dianggap keramat, tempat pemakaman tokoh atau pimpinan yang dianggap legenda. Contoh makam Bung Karno di Blitar, Makam Wali Songo, tempat ibadah seperti di Candi Borobudur, Pura Besakih di Bali, Sendang Sono di Jawa Tengah dan sebagainya.

n. Wisata Bulan Madu, Suatu penyelenggaraan perjalanan bagi pasangan-pasangan, pengantin baru, yang sedang berbulan madu dengan fasilitasfasilitas khusus dan tersendiri demi kenikmatan perjalanan dan kunjungan mereka.

\section{Pendekatan Pariwisata}

Terdapat empat pendekatan-pendekatan dalam pariwisata antara lain yaitu, (Spillane (1994) :

\section{a. PendekatanAdaptancy,}

Pendekatan ini menyebutkan agar pengaruh negatif pariwisata dapat dikontrol dengan mencari bentuk lain perkembangan pariwisata dari yang selama ini sudah dikenal secara umum, atau dengan menyesuaikan pariwisata dengan Negara atau daerah tujuan wisata. Cara berpikir baru ini berdasarkan pandangan bahwa alam dan budaya dapat digabungkan dalam satu konteks.

b. Pendekatan Developmental, Pendekatan Developmental atau sering disebut pendekatan
Alternative ini menganggap bahwa pariwisata dapat disesuaikan dengan keadaan masyarakat tuan rumah dan peka akan selera masyarakat tuan rumah tersebut Dapat dipercaya bahwa perkembangan tersebut sebetulnya mempengaruhi pilihan wisatawan terhadap daerah tujuan wisatanya dan demikian juga kehidupan mereka didaerah tujuan wisata atau bentuk alternative pariwisata ini mempengaruhi jurang pemisah antara hak dan kewajiban dari tamu, tuan rumah dan perantaranya.

c. PendekatanAdvocasy

Pendekatan ini mendukung pariwisata dan menekankan keuntungan ekonomis dari pariwisata. Potensi pariwisata bisa dipakai untuk mendukung macammacam kegiatan ekonomis, menciptakan lapangan kerja baru, memperoleh devisa asing yang dibutuhkan bagi pembangunan dan masih banyak lagi.

d. PendekatanCautionary,

Pendekatan ini menekankan bahwa pariwisata banyak mengakibatkan banyak kerugian (disbenefits) dalam berbagai aspek sosial-ekonomi: seperti menimbulkan lapangan kerja musiman dan kasar (rendahan), mengakibatkan kebocoran devisa asing, menyebabkan komersialisasi budaya, serta menyebabkan berbagai macam konflik.

\section{Objek Wisata \\ Definisi Objek Wisata}

Yoeti (1997) mendifinisikan objek wisata sebagai berbagai macam hal yang dapat dilihat, disaksikan, dilakukan atau dirasakan. Sedangkan Suwantoro (1997) mendifinisikan objek wisata sebagai potensi yang menjadi pendorong kehadiran wisatawan kesuatu daerah, dan objek wisata dibagi menjadi :

1. Obyek wisata dan daya tarik wisata alam, dimana obyek wisata ini memiliki daya tarik yang bersumber dari keindahan dan kekayaan alam.

2. Obyek wisata dan daya tarik budaya, dimana obyek dan daya tarik wisata ini bersumber dari kebudayaan, seperti 
peninggalan sejarah, museum, atraksi kesenian, dan obyek lain yang berkaitan dengan budaya

3. Obyek wisata dan daya tarik pada minat khusus, dimana daya tarik dari obyek wisata ini bersumber dari minat khusus wisatawan itu sendiri, seperti olah raga, memancing dan sebagainya.

\section{Pemasaran \\ Definisi Pemasaran}

Menurut Kotler (1997;8) Pemasaran adalah suatu proses sosial dan manajerial yang di dalamnya individu dan kelompok mendapatkan apa yang mereka butuhkan dan inginkan dengan menciptakan, menawarkan, dan mempertukarkan produk yang bernilai dengan pihak lain. Konsep inti dalam pemasaran adalah kebutuhan, keinginan, permintaan, produk, nilai, biaya, kepuasan, pertukaran, hubungan, jaringan, pasar dan pemasar.

\section{Perilaku konsumen \\ Definisi Perilaku Konsumen}

Perilaku konsumen merupakan tindakan langsung dalam mendapatkan, mengkonsumsi serta menghabiskan produk dan jasa, termasuk proses keputusan yang mendahului dan mengikuti tindakan tersebut (Umar,2001:). Perilaku konsumen dibagi menjadi dua golongan:

1. Perilaku yang tampak (jumlah pembelian, waktu pembelian, dengan siapa melakukan pembelian, bagaimana konsumen melakukan pembelian.

2. Perilaku yang tidak tampak (persepsi, ingatan terhadap informasi, perasaan kepemilikan oleh konsumen

Menurut Rangkuti $(2006,58)$ terdapat tiga jenis definisi berkaitan dengan perilaku konsumen, yaitu ;

1. Perilaku konsumen adalah dinamis, artinya perilaku konsumen menekankan bahwa seorang konsumen, kelompok konsumen, serta masyarakat luas selalu bergerak dan berubah sepanjang waktu. Di dalam pengembangan startegi pemasaran sifat dinamis perilaku konsumen menyiratkan bahwa seseorang tidak bolah berharap bahwa satu strategi pemasaran yang sama dapat memberikan hasil yang sama sepanjang waktu, di pasar dan industri yang sama.

2. Perilaku konsumen melibatkan pertukaran yang menekankan bahwa konsumen tetap konsisten dengan definisi pemasaran yang sejauh ini berkaitan dengan pertukaran.

3. Perilaku konsumen melibatkan interaksi, menekankan bahwa untuk mengembangkan strategi pemasaran yang tepat, kita harus memahami yang dipikirkan, dirasakan, dan dilakukan oleh konsumen. Selain itu juga harus dipahami apa dan dimana peristiwa kejadian sekitar yang dipengaruhi oleh pikiran, perasaan dan tindakan konsumen.

\section{Faktor-faktor yang mempengaruhi perilaku pembelian}

1. Faktor budaya

Faktor budaya memiliki pengaruh yang luas dan mendalam terhadap perilaku budaya. Perilaku budaya terdiri dari (Simamora,2008;7) ;

a. kultur, yang menjadi penentu paling utama dari keinginan dan perilaku seseorang

b. subkultur, setiap kultur memiliki subkultur yang lebih kecil atau kelompok orang dengan sistem nilai yang sama berdasarkan pengalaman dan situasi hidup yang sama

c. kelas sosial, susunan yang relatif permanen dan teratur dalam suatu masyarakat yang anggotanya memiliki minat dan perilaku yang sama.

2. Faktor sosial, faktor sosial ini dipengaruhi oleh gaya hidup, kelas sosial dan tingkat sosial konsumen.

3. Faktor pribadi, keputusan seseorang yang melakukan pembelian barang dipengaruhi oleh karakteristik pribadi seperti ; umur dan daur hidup pembeli, gaya hidup, keadaan ekonomi, jabatan, kepribadian dan konsep diri pembeli yang bersangkutan. 
4. Faktor psikologis, suatu kebutuhan muncul akibat adanya keadaan fisiologis seperti rasa haus, lapar dan sebagainya. Kebutuhan Fisiologis terdiri dari motivasi, persepsi, proses belajar, kepercayaan dan sikap.

\section{Kepuasan Konsumen \\ Definisi Kepuasan konsumen}

Kepuasan konsumen merupakan tingkat perasaan konsumen setelah membandingkan antara apa yang dia terima dan harapannya (Umar,2001). Jika konsumen puas, maka besar kemungkinan konsumen tersebut akan menjadi pelanggan dalam waktu yang lama.

Sedangkan menurut Kotler (1997) kepuasan merupakan perasaan senang dan kecewa sesorang yang berasal dari perbandingan antara kesannya terhadap kinerja/hasil suatu produk dan harapannya.

Harapan konsumen biasanya terbentuk atau dipengaruhi oleh pengalaman pembelian (penggunaan terhadap suatu produk/jasa) mereka sebelumnya seperti kecepatan dan ketepatan pelayanan, kelengkapan suatu produk

Pengertian kepuasan pelanggan mencakup perbedaan antara tingkat kepentingan (harapan) dan hasil yang dirasakan dan dapat diaplikasikan pada penilaian kepuasan dan ketidak puasan terhadap satu perusahaan tertentu karena keduanya berkaitan erat dengan konsep kepuasan pelanggan yang terlihat pada gambar konsep kepuasan pelanggan (Rangkuti,2006;24).

\section{Metode pengukuran kepuasan pelanggan}

Pada metode penelitian yang dilakukan dengan menggunakan metode survei, maka pengukuran kepuasan pelanggan dilakukan dengan cara (Rangkuti,2006;24);

1. Pengukuran dapat dilakukan secara langsung melalui pertanyaan kepada pelanggan dengan ungkapan sangat tidak puas, kurang puas, cukup puas, puas dan sangat puas.

2. Responden diberi pertanyaan berkaitan dengan seberapa besar mereka mengharapkan atribut tertentu dan seberapa besar yang mereka rasakan dari atribut tersebut.

3. Responden diminta menuliskan masalah-masalah yang mereka hadapi yang berhubungan dengan penawaran dari perusahaan dan diminta untuk menuliskan perbaikan-perbaikan yang mereka sarankan.

4. Responden diminta merangking elemen/atribut penawaran berdasarkan derajad kepentingan setiap elemen dan seberapa baik kinerja perusahaan pada masingmasing elemen.

\section{Faktor-faktor yang mempengaruhi kepuasan konsumen}

Salah satu faktor yang menentukan kepuasan pelanggan adalah persepsi pelanggan berkaitan dengan kualitas jasa yang berfokus pada lima dimensi jasa, kualitas produk dan harga serta faktorfaktor yang bersifat pribadi.

Menurut Rangkuti (2006,31- 40) Faktorfaktor yang mempengaruhi kepuasan konsumen

1. Value (Nilai).

Nilai diartikan sebagai pengkajian secara menyeluruh manfaat dari suatu produk berdasarkan persepsi pelanggan atas apa yang telah diterima oleh pelanggan dan yang telah diberikan oleh produk tersebut. Pelanggan akan semakin loyal jika produk tersebut bernilai baginya dan perusahaan yang memiliki reputasi produk bernilai tinggi dapat menerapkan harga lebih tinggi diabndingkan dengan harga pesaing.

2. Daya saing.

Perusahaan yang menginginkan produknya diterima oleh konsumen harus memiliki daya saing yang tinggi. Suatu produk hanya memiliki daya saing jika keunggulan produk tersebut dibutuhkan oleh pelanggan yaitu produk yang memiliki keunikan dan kualitas pelayanan produk jasa tersebut kepada pelanggan.

3. Image (Citra).

Suatu produk yang memiliki citra yang buruk akan menimbulkan persepsi 
produk yang buruk di mata konsumen, sebaliknya produk yang memiliki citra yang baik akan menimbulkan persepsi yang baik juga terhadap suatu produk.

4. Kualitas Pelayanan

5. Harga produk

\section{Marketing Mix Strategy (Strategi Bauran Pemasaran)}

Strategi Bauran Pemasaran diartikan sebagai strategi pemasaran yang terdiri dari kebijakan product (produk), kebijakan price (harga), kebijakan place (distribusi) dan kebijakan promotion(promosi)).

a. Kebijakan produk

Produk yang dihasilkan harus berkualitas, standar ukuran kualitas suatu produk terdiri dari : Performance (kinerja), Durability (Daya tahan), Features (sifat \& jenisnya), Serviceability (kecepatan, kemudahan, akurasi), Realibility (daya tahan), Aesthetics (pertimbangan pribadi), Conformance (kenyamanan), Fit and Finish (keberadaan suatu produk)

b. Kebijakan harga

Menurut Kotler $(2000,19)$ pendekatan umum dalam penetapan harga antara lain :

Penetapan harga berdasarkan biaya, terdiri dari:

1. Penetapan harga cost plus

2. Penetapan harga dg analisis titik impas \& laba sasaran

3. Penetapan harga berdasarkan nilai

Sedangkan penetapan harga berdasarkan persaingan, terdiri dari:

1. Penetapan harga menurut keadaan

\section{Penetapan}

harga penawaran tertutup

c. Kebijakan distribusi

Ada beberapa tingkatan saluran dan panjang saluran distribusi (Umar, 2003;134):

a. Tingkat saluran 0 , panjang saluran ini tidak memiliki perantara, langsung dari produsen ke konsumen. b. Tingkat saluran 1, panjang saluran ini mempunyai satu tingkatan pedagang perantara seperti pengecer

c. Tingkat saluran 2, panjang saluran ini mempunyai dua tingkatan pedagang perantara, contohnya grosir selanjutnya ke pengecer

d. Tingkat saluran 3, panjang saluran ini memiliki tiga tingkatan pedagang perantara yaitu produsen, pedagang besar (grosir), kemudian ke pengecer.

d. Kebijakan promosi

Di dalam promosi terdapat empat komponen utama dalam bauran promosi yaitu

1. periklanan

2. promosi penjualan

3. hubungan masyarakat dan

4. penjualan perorangan

\section{Pemasaran Pariwisata}

Pemasaran pariwisata diartikan sebagai proses manajerial yang mengantisipasi dan memuaskan keinginan pengunjung yang ada dan calon pengunjung secara lebih efektif dari pemasok dan destinasi pesaing. Perubahan dalam manajemen dipacu oleh laba dan manfaat bagi masyarakat. Lumsdon (1977) dalam Vellas \& Becherel (1999)

Ciri-ciri penting pemasaran pariwisata Seaton \& Benelt (1996) dalam Vellas \& Becherel (1999)

a. Filosofi yang berorientasi pada konsumen

b. Prosedur dan konsep analitik

c. Teknik pengumpulan data

d. Struktur organisasi

e. Wilayah keputusan startegis dan fungsi perencanaan

\section{METODE PENELITIAN}

\section{Jenis Penelitian}

Jenis penelitian yang digunakandalam penelitian ini adalah penelitian deskriptif.Penentuan lokasi penelitian dilakukan secara purposive sampling yaitu menentukan lokasi penelitian secara 
sengaja, lokasi penelitian adalah Kabupaten Lombok Utara (KLU)

\section{Jenis dan Sumber Data \\ Jenis data}

Jenis data dalam penelitian ini adalah :

a. Data kuantitatif yaitu data yang diperlukan dalam penelitian yang berupa angka angka yang dapat diukur besarnya dan dapat dihitung secara pasti.

b. Data kualitatif yaitu data yang diperlukan dalam penelitian ini berupa keterangan dan kebijakan yang berkaitan dengan pemasaran dan pengembangan pariwisata di kabupaten Lombok utara (KLU)

\section{Sumber data}

data yang digunakan dalam penelitian ini adalah data sekunder, yaitu data yang pengguna tidak mengambil langsung dari responden/objek penelitian tetapi sudah dalam bentuk data jadi yang tersedia pada instansi atau lembaga pengumpul data seperti BPS, bank Indonesia, dan instansi lainnya penyedia data lainnya.

\section{Metode dan Teknik pengumpulan data} Metode pengumpulan data yang digunakan dalam penelitian ini adalah metode studi kasus, dimana peneliti ingin mencari strategi pemasaran yang sesuai, bauran pemasaran dan pengembangan pariwisata di Kabupaten Lombok Utara Teknik yang digunakan dalam mengumpulkan data dalam penelitian ini adalah sebagai berikut:

1. Dokumentasi yaitu pengumpulan data berupa catatan-catatan yang tersedia pada lembaga terkait

2. Study kepustakaan, yaitu pengumpulan data dengan cara penelahaan kepustakaan dengan obyek- obyek yang akan dibahas dan bahan bacaan yang berhubungan dengan masalah yang diteliti.

\section{Teknik Analisis Penelitian}

Analisis data yang digunakan dalam penelitian ini adalah analisis deskriptif dan analisisSWOT(Strength,Weakness,Opport unity,Treath). Analisis ini membandingkan antara faktor eksternal peluang (opportunities) dan ancaman (threats) dengan faktor internal kekuatan (strengths) dan kelemahan (weaknesses)

\begin{tabular}{|l|l|l|}
\hline \multicolumn{1}{|c|}{$\begin{array}{l}\text { Gambar 1 Matrik SWOT } \\
\text { Eksternal }\end{array}$} & $\begin{array}{l}\text { STRENGTHS (S) } \\
\text { Internal } \\
\text { Tentukan 5-10 } \\
\text { kekuatan internal }\end{array}$ & $\begin{array}{l}\text { WEAKNESSES (W) } \\
\text { Tentukan 5-10 faktor } \\
\text { kelemahan internal }\end{array}$ \\
\hline $\begin{array}{l}\text { OPPORTUNITIES (O) } \\
\text { Tentukan 5-10 peluang } \\
\text { eksternal }\end{array}$ & $\begin{array}{l}\text { STRATEGI SO } \\
\text { Ciptakan strategi yang } \\
\text { menggunakan kekuatan } \\
\text { untuk memanfaatkan } \\
\text { peluang }\end{array}$ & $\begin{array}{l}\text { STRATEGI WO } \\
\text { Ciptakan strategi yang } \\
\text { meminimalkan } \\
\text { kelemahan untuk } \\
\text { memanfaatkan peluang }\end{array}$ \\
\hline $\begin{array}{l}\text { THREATS (T) } \\
\text { Tentukan 5-10 ancaman } \\
\text { eksternal }\end{array}$ & $\begin{array}{l}\text { STRATEGI ST } \\
\text { Ciptakan strategi yang } \\
\text { menggunakan kekuatan } \\
\text { untuk mengatasi } \\
\text { ancaman }\end{array}$ & $\begin{array}{l}\text { STRATEGI WT } \\
\text { Ciptakan strategi yang } \\
\text { meminimalkan } \\
\text { kelemahan dan } \\
\text { menghindari ancaman }\end{array}$ \\
\hline
\end{tabular}

Sumber: (Rangkuti, 2002:31

\section{HASIL PENELITIAN}

Strategi pemasaran pariwisata melalui bauran pemasaran (marketing mix) Kabupaten Lombok Utara (KLU)

Dalam proses pemasaran pariwisata di kabupaten lombok utara (KLU), kegiatan yang harus dilakukan pertama kali adalah melakukan analisis pasar (permintaan pasar konsumen), analisis ini dilalakukan untuk mengetahui sejauh mana potensi pasar yang dimiliki oleh pariwisata di Kabupaten Lombok Utara (KLU), tujuan utama dari kegiatan ini adalah melihat 
potensi konsumen untuk berkunjung ke daerah/tempat wisata yang berada di Kabupaten Lombok Utara (KLU) baik dilihat dari kondisi alam, keindahan, kenyamanan, dan keamanan. Potensi ini cukup baik jika dilihat potensi konsumen yang dimiliki baik konsumen (wisatawan) dari domestic (NTB dan Indonesia) serta konsumen mancanegara dan juga potensi keindahan tempat atau tujuan wisata di Kabupaten Lombok Utara (KLU).

Setelah analisis pasar dilakukan maka kegiatan selanjutnya adalah melakukan segmentasi pasar, dimana segmentasi ini diartikan membagi konsumen ke dalam berbagai segmen atau bagian, misalnya konsumen yang dibagi ke dalam segmen berdasarkan jenis kelamin yaitu segmen laki-laki dan perempuan, konsumen yang dibagi berdasarkan segmen usia seperti anak-anak, remaja dan dewasa serta segmen lainnya yang semua segmen tersebut memiliki karakteristik dan ciri khas masing-masing. Pada pemasaran pariwisata di Kabupaten Lombok Utara (KLU) harus pilih segmen pasar yang paling potensial seperti segmen berdasarkan usia yaitu usia remaja yang memiliki rentang usia 30-50 tahun, dimana segmen ini sangat potensial karena pada usia inilah masyarakat senang untuk berwisata sehingga dinasa pariwisata Kabupaten Lombok Utara (KLU) harus memberikan pelayanan pariwisata sesuai dengan kebutuhan segmen usia remaja tersebut.

Kegiatan selanjutnya dalam kegiatan pemasaran pariwisata di Kabupaten Lombok Utara (KLU) adalah menentukan kebutuhan wisatawan, yaitu menentukan factor-faktor apa yang mempengaruhi pemilihan tempat wisata oleh wisatawan asing maupun domestic di Kabupaten Lombok Utara (KLU), dimana factor-faktor tersebut adalah sebagai berikut :

a. Keunikan di tempat wisata

b. Budaya masyarakat di kawasan wisata

c. Sikap masyarakat (keramahan) di kawasan wisata

d. Kondisi keamanan di kawasan wisata

e. Sarana dan prasarana di kawasan wisata

f. Palayanan kepada wisatawan di kawasan wisata g. Kebersihan lingkungan di kawasan wisata

h. Penataan lingkungan di kawasan wisata

i. Letak daerah wisata yang strategis

j. Menjadi destinasi wisata di Pulau Lombok.

k. Memiliki keunikan dan kekhasan wisata

Strategi selanjutnya dalam kegiatan pemasaran pariwisata yaitu strategi marketing mix (bauran pemasaran) seperti strategi-strategi marketing mix (bauran pemasaran) di bawah ini:

Strategi Produk (Product), strategi produk dalam pariwisata di artikan sebagai daerah wisata atau tujuan wisata harus di kemas dengan semenarik mungkin seperti ciri khas yang dimiliki oleh daerah wisata di KLU, keunggulan objek wisata di KLU dengan objek wisata lainnya, tempat wisata yang aman, nyaman, bersih. Selain itu juga harus di buat paket wisata atau tujuan wisata yang dibuat oleh Dinas pariwisata kabupaten Lombok utara untuk memudahkan wisatawan asing maupun domestic untuk menggunakan produk dan jasa wisata kabupaten Lombok utara.

Strategi harga (price), harga atau biaya yang dikeluarkan oleh wisatawan asing maupun domestic yang ingin berkunjung ke daerah wisata haruslah terjangkau terutama biaya yang dikeluarkan untuk transportasi dan tiket masuk ke seluruh tempat atau objek wisata yang ada di kabupaten Lombok utara. Penentuan harga pariwisata diartikan sebagai sejumlah uang yang dikeluarkan oleh seorang wisatawan untuk memperoleh jasa pariwisata, dimana besarnya jumlah uang yang dikeluarkan tergantung dari tingkat kebutuhan dan keinginan wisatawan, Kurs rupiah terhadap dollar AS, inflasi daerah (Nusa Tenggara Barat) sehingga penentuan harga pariwisata dapat dijangkau oleh wisatawan asing maupun domestic.

\section{Strategi Place (Distribusi)}

Distribusi pariwisata diartikan sebagai produk-produk pariwisata dapat terdistribusi dengan murah, cepat dan 
mudah kepada wisatawan. System distribusi pariwisata yang efektif adalah distribusi pariwisata yang mudah dan memiliki saluran distribusi yang pendek dan cepat dari agen wisata atau travel langsung kepada wisatawan (konsumen) sampai dengan shoping center (pusat oleh-oleh).

\section{Kebijakan promotion (promosi)}

Promosi pariwisata diartikan sebagai segala bentuk kebijakan promosi yang dapat memberikan kemudahan dan pemahaman terhadap segala informasi yang berkaitan dengan pariwisat di lokasi atau objek tertentu seperti promosi yang harus dilakukan oleh stakeholder pariwisata di KLU seperti promosi melalui

a. Media cetak (brosur, Koran, majalah pariwisata)

b. Media elektronik (internet, media social

(facebook,twiter,instagram)), blog, televisi, chanel youtube, dan sebagainya)

c. Menggelar ivent-ivent pariwisata

d. Mengikuti pameran-pameran pariwisata di dalam maupun di luar negeri

\section{Analisis SWOT (Kekuatan, Kelemahan, Ancaman, Peluang) pariwisata Kabupaten Lombok Utara (KLU) Analisis SWOT factor internal (Kekuatan) Pariwisata KLU}

Tabel 3 Tabel Analisis SWOT factor internal (Kekuatan) Pariwisata KLU

\begin{tabular}{|l|l|}
\hline No & Faktor internal \\
\hline & KEKUATAN \\
\hline 1 & Keunikan di tempat wisata \\
\hline 2 & Budaya masyarakat di kawasan wisata \\
\hline 3 & Sikap masyarakat (keramahan) di kawasan wisata \\
\hline 4 & Aksebilitas ke kawasan wisata \\
\hline 5 & Kondisi keamanan di kawasan wisata \\
\hline
\end{tabular}

Dari tabel 3 analisis SWOT penelitian dengan melihat factor internal Pariwisata KLU dengan menggunakan 5 Faktor seperti Keunikan di tempat wisata, Budaya masyarakat di kawasan wisata, Sikap masyarakat (keramahan) di kawasan wisata, Aksebilitas ke kawasan wisata, Kondisi keamanan di kawasan wisata dimana Faktor strategi internal (kekuatan) yang memiliki kekuatan utama adalah Keunikan di tempat wisata, artinya objek wisata di KLU harus memiliki keunikan atau ciri khas karena biasanya wisatawan mencari daerah wisata yang memiliki keunikan dan berbeda dengan objek wisata di daerah lainnya, selain itu juga wisatawan tidak akan mau untuk mencari daerah wisata yang biasa-biasa saja atau sudah ada di daerah lain sehingga perlu di atur sedemikian rupa oleh stakeholder pariwisata agar objek wisata di KLU disukai dan menjadi tujuan wisata di pulau Lombok.

\section{Analisis SWOT factor internal (Kelemahan) Pariwisata KLU}

Tabel 4 Tabel Analisis SWOT factor internal (Kelemahan) Pariwisata KLU

\begin{tabular}{|c|l|}
\hline No & Faktor internal \\
\hline & KELEMAHAN \\
\hline 1 & Palayanan kepada wisatawan di kawasan wisata \\
\hline 2 & Kebersihan lingkungan di kawasan wisata \\
\hline 3 & Penataan lingkungan di kawasan wisata \\
\hline 4 & Sarana dan prasarana yang kurang \\
\hline 5 & SDM pemandu wisata masih kurang \\
\hline
\end{tabular}


Dari tabel 4 analisis SWOT penelitian dengan melihat factor internal Pariwisata KLU dengan menggunakan 5 Faktor seperti Faktor Palayanan kepada wisatawan di kawasan wisata, Kebersihan lingkungan di kawasan wisata, Penataan lingkungan di kawasan wisata, Sarana dan prasarana yang kurang, SDM pemandu wisata masih kurang, dimana Faktor strategi internal (Kelemahan) yang memiliki kelemahan yang utama adalah Faktor Palayanan kepada wisatawan di kawasan wisata artinya pelayanan peiwisata di sejumlah objek wisata di daerah kabupaten Lombok utara (KLU) masih kurang karena pelaku wisata di KLU kurang memperhatikan pelayana kepada wisatawan Karena masih menjadikan keuntungan materi sebagai tujuan utama dari pelayanan pariwisata sehingga kadangkala mengabaikan pelayanan prima kepada wisatawan, terutama pelayanan kepada wisatawan asing, dimana kadangkal pelaku wisata memanfaatkan wisatawan asing dengan mengenakan harga atau biaya pariwisata ke pada wisatawan asing dengan tarif yang cukup tinggi.

\section{Analisis SWOT factor eksternal (Peluang) Pariwisata KLU}

Tabel 5 Tabel Analisis SWOT factor eksternal (Peluang) Pariwisata KLU

\begin{tabular}{|c|l|}
\hline No & Faktor eksternal \\
\hline & PELUANG \\
\hline 1 & Letak daerah wisata yang strategis \\
\hline 2 & Menjadi destinasi wisata di Pulau Lombok. \\
\hline 3 & Memiliki kekhasan produk wisata \\
\hline 4 & Promosi pariwisata yg gencar \\
\hline 5 & Dukungan dari stakeholder periwisata \\
\hline
\end{tabular}

Sumber : data diolah

Dari tabel 5 analisis SWOT penelitian dengan melihat factor eksternal Pariwisata KLU dengan menggunakan 5 Faktor seperti Faktor Letak daerah wisata yang strategis, Menjadi destinasi wisata di Pulau Lombok, Memiliki kekhasan produk wisata, Promosi pariwisata yg gencar, Dukungan dari stakeholder periwisata dimana Peluang utama pariwisata KLU adalah Letak daerah wisata yang strategis karena secara geografis daerah KLU dekat dengan wilayah wisata senggigi yang menjadi daya tarik wisatawan asing dan domestic sehingga dapat menjadi tujuan utama dan tujuan alternative daerah kunjungan wisatawan. Selain itu juga letak daerah wisata KLU yang berada di daerah perbukitan dan pegunungan memberikan ciri khas objek wisata yang dapat di jual kepada wisatawan, belum lagi adanya budaya masyarakat sekitar objek wisata yang dapat dijadikan produk wisata yang dapat dikemas dengan baik.

\section{Analisis SWOT factor eksternal (Ancaman) Pariwisata KLU}

Tabel 6 Tabel Analisis SWOT factor eksternal (Ancaman) Pariwisata KLU

\begin{tabular}{|l|l|}
\hline No & Faktor eksternal \\
\hline & ANCAMAN \\
\hline 1 & Persaingan pariwisata semakin ketat \\
\hline 2 & Perubahan perilaku masyarakat \\
\hline 3 & Perubahan budaya masyarakat \\
\hline 4 & Harga pariwisata yg tinggi \\
\hline 5 & Tercemarnya lingkungan \\
\hline
\end{tabular}

Sumber : data diolah 
Dari tabel 6 analisis SWOT penelitian dengan melihat factor eksternal Pariwisata KLU dengan menggunakan 5 Faktor seperti Faktor Persaingan pariwisata semakin ketat, Perubahan perilaku masyarakat, Perubahan budaya masyarakat, Harga pariwisata yg tinggi, Tercemarnya lingkungan dimana Faktor strategi Eksternal (Ancaman) yang memiliki ancaman utama adalah Persaingan pariwisata yang semakin ketat artinya pariwisata di KLU mendapat ancaman utama untuk berkembang dari pesaing pariwisata di daerah lain terutama dari daerah yang secara historis menjadi tujuan wisatawan sebelumnya seperti daerah wisata di Lombok tengah dan Lombok barat sehingga perlu adanya strategi khusus dalam mengemas produk pariwisata di daerah KLU ini dengan menambahkan unsur budaya dalam objek wisata tersebut dan adanya peran serta stakeholder pariwisata yang tinggi dalam mengatur dan mengelola pariwisata di KLU agar dapat menjadi tujuan atau destinasi wisata yang utama di pulau Lombok.

\section{Srategi pengembangan pariwisata Kabupaten Lombok Utara (KLU)}

Dari hasil analisis SWOT diatas juga dapat dirumuskan strategi pengembangan Pariwisata di KLU sebagai berikut ;

1. Adanya peran serta stakeholder pariwisata dalam membangun pariwisata di KLU khususnya pelaku wisata yang berhubungan langsung dengan kepariwisataan serta masyarakat yang berada disekitar daerah wisata di kabupaten Lombok utara (KLU)

2. Dinas pariwisata kabupaten Lombok utara (KLU) harus sering mengadakan iven-iven pariwisata di kabupaten Lombok utara (KLU) agar wisatawan dapat menikmati kegiatan pariwisata tersebut

3. Harus dilakukan promosi secara komprehensip terutama promosi melalui media social, televisi dan memperbanyak brosur untuk memudahkan wisatawan dalam memperoleh informasi perjalanan wisata di kabupaten Lombok utara
4. Meningkatkan kualitas sumber daya manusia pemandu wisata dan meningkatkan pemahaman sadar wisata ke masyarakat yang berada di sekitar objek wisata di kabupaten Lombok utara (KLU) agar wisatawan dapat terlayani dengan baik.

5. Memperbaiki dan Melengkapi sarana dan prasarana pariwisata terutama objek wisata yang berada di wialayah sekitar objek wisata di kabupaten Lombok utara (KLU)

6. Stakeholder pariwisata harus sering mengikuti promosi-promosi pariwisata yang diselenggarakan di dalam negeri dan diluar negeri karena bisa langsung dimanfaatkan untuk dapat menarik wisatawan domestic maupun wisatawan asing.

\section{Pembahasan}

Dengan melihat factor internal Pariwisata KLU dengan menggunakan 5 Faktor seperti Keunikan di tempat wisata, Budaya masyarakat di kawasan wisata, Sikap masyarakat (keramahan) di kawasan wisata, Aksebilitas ke kawasan wisata, Kondisi keamanan di kawasan wisata dimana Faktor strategi internal (kekuatan) yang memiliki kekuatan utama adalah Keunikan di tempat wisata, artinya objek wisata di KLU harus memiliki keunikan atau cirri khas karena biasanya wisatawan mencari daerah wisata yang memiliki keunikan dan berbeda dengan objek wisata di daerah lainnya, selain itu juga wisatawan tidak akan mau untuk mencari daerah wisata yang biasa-biasa saja atau sudah ada di daerah lain sehingga perlu di atur sedemikian rupa oleh stakeholder pariwisata agar objek wisata di KLU disukai dan menjadi tujuan wisata di pulau Lombok.

Dengan melihat factor internal Pariwisata KLU dengan menggunakan 5 Faktor seperti Faktor Palayanan kepada wisatawan di kawasan wisata, Kebersihan lingkungan di kawasan wisata, Penataan lingkungan di kawasan wisata, Sarana dan prasarana yang kurang, SDM pemandu wisata masih kurang, dimana Faktor strategi internal (Kelemahan) yang 
memiliki kelemahan yang utama adalah Faktor Palayanan kepada wisatawan di kawasan wisata artinya pelayanan peiwisata di sejumlah objek wisata di daerah kabupaten Lombok utara (KLU) masih kurang karena pelaku wisata di KLU kurang memperhatikan pelayana kepada wisatawan Karena masih menjadikan keuntungan materi sebagai tujuan utama dari pelayanan pariwisata sehingga kadangkala mengabaikan pelayanan prima kepada wisatawan, terutama pelayanan kepada wisatawan asing, dimana kadangkal pelaku wisata memanfaatkan wisatawan asing dengan mengenakan harga atau biaya pariwisata ke pada wisatawan asing dengan tarif yang cukup tinggi.

Dengan melihat factor eksternal Pariwisata KLU dengan menggunakan 5 Faktor seperti Faktor Letak daerah wisata yang strategis, Menjadi destinasi wisata di Pulau Lombok, Memiliki kekhasan produk wisata, Promosi pariwisata yg gencar, Dukungan dari stakeholder periwisata dimana Peluang utama pariwisata KLU adalah Letak daerah wisata yang strategis karena secara geografis daerah KLU dekat dengan wilayah wisata senggigi yang menjadi daya tarik wisatawan asing dan domestic sehingga dapat menjadi tujuan utama dan tujuan alternative daerah kunjungan wisatawan. Selain itu juga letak daerah wisata KLU yang berada di daerah perbukitan dan pegunungan memberikan ciri khas objek wisata yang dapat di jual kepada wisatawan, belum lagi adanya budaya masyarakat sekitar objek wisata yang dapat dijadikan produk wisata yang dapat dikemas dengan baik.

Dengan melihat factor eksternal Pariwisata KLU dengan menggunakan 5 Faktor seperti Faktor Persaingan pariwisata semakin ketat, Perubahan perilaku masyarakat, Perubahan budaya masyarakat, Harga pariwisata yg tinggi, Tercemarnya lingkungan dimana Faktor strategi Eksternal (Ancaman) yang memiliki ancaman utama adalah Persaingan pariwisata yang semakin ketat artinya pariwisata di KLU mendapat ancaman utama untuk berkembang dari pesaing pariwisata di daerah lain terutama dari daerah yang secara historis menjadi tujuan wisatawan sebelumnya seperti daerah wisata di Lombok tengah dan Lombok barat sehingga perlu adanya strategi khusus dalam mengemas produk pariwisata di daerah KLU ini dengan menambahkan unsur budaya dalam objek wisata tersebut dan adanya peran serta stakeholder pariwisata yang tinggi dalam mengatur dan mengelola pariwisata di KLU agar dapat menjadi tujuan atau destinasi wisata yang utama di pulau Lombok.

Dari hasil analisis SWOT diatas juga dapat dirumuskan strategi pengembangan Pariwisata di KLU sebagai berikut ;

1. Adanya peran serta stakeholder pariwisata dalam membangun pariwisata di KLU khususnya pelaku wisata yang berhubungan langsung dengan kepariwisataan serta masyarakat yang berada disekitar daerah wisata di kabupaten Lombok utara (KLU)

2. Dinas pariwisata kabupaten Lombok utara (KLU) harus sering mengadakan iven-iven pariwisata di kabupaten Lombok utara (KLU) agar wisatawan dapat menikmati kegiatan pariwisata tersebut

3. Harus dilakukan promosi secara komprehensip terutama promosi melalui media social, televisi dan memperbanyak brosur untuk memudahkan wisatawan dalam memperoleh informasi perjalanan wisata di kabupaten Lombok utara

4. Meningkatkan kualitas sumber daya manusia pemandu wisata dan meningkatkan pemahaman sadar wisata ke masyarakat yang berada di sekitar objek wisata di kabupaten Lombok utara (KLU) agar wisatawan dapat terlayani dengan baik.

5. Memperbaiki dan Melengkapi sarana dan prasarana pariwisata terutama objek wisata yang berada di wialayah sekitar objek wisata di kabupaten Lombok utara (KLU)

6. Stakeholder pariwisata harus sering mengikuti promosi-promosi pariwisata yang diselenggarakan di dalam negeri dan diluar negeri karena bisa langsung dimanfaatkan untuk dapat menarik 
wisatawan domestic maupun wisatawan asing.

\section{KESIMPULAN DAN SARAN}

\section{Kesimpulan}

1. Faktor strategi internal (kekuatan) yang memiliki kekuatan utama adalah Keunikan di tempat wisata, artinya objek wisata di KLU harus memiliki keunikan atau ciri khas karena biasanya wisatawan mencari daerah wisata yang memiliki keunikan dan berbeda dengan objek wisata di daerah lainnya

2. Faktor strategi internal (Kelemahan) yang memiliki kelemahan yang utama adalah Faktor Palayanan kepada wisatawan di kawasan wisata artinya pelayanan peiwisata di sejumlah objek wisata di daerah kabupaten Lombok utara (KLU) masih kurang karena pelaku wisata di KLU kurang memperhatikan pelayana kepada wisatawan

3. Peluang utama pariwisata KLU adalah Letak daerah wisata yang strategis karena secara geografis daerah KLU dekat dengan wilayah wisata senggigi yang menjadi daya tarik wisatawan asing dan domestic sehingga dapat menjadi tujuan utama dan tujuan alternative daerah kunjungan wisatawan

4. Faktor strategi Eksternal (Ancaman) yang memiliki ancaman utama adalah Persaingan pariwisata yang semakin ketat artinya pariwisata di KLU mendapat ancaman utama untuk berkembang dari pesaing pariwisata di daerah lain terutama dari daerah yang secara historis menjadi tujuan wisatawan sebelumnya seperti daerah wisata di Lombok tengah dan Lombok barat sehingga perlu adanya strategi khusus dalam mengemas produk pariwisata di daerah KLU

5. Strategi pengembangan pariwisata di KLU antara lain Dinas pariwisata kabupaten Lombok utara (KLU) harus sering mengadakan iven-iven pariwisata di kabupaten Lombok utara (KLU) agar wisatawan dapat menikmati kegiatan pariwisata tersebut, Harus dilakukan promosi secara komprehensip terutama promosi melalui media social, televisi dan memperbanyak brosur untuk memudahkan wisatawan dalam memperoleh informasi perjalanan wisata di kabupaten Lombok utara, Meningkatkan kualitas sumber daya manusia pemandu wisata dan meningkatkan pemahaman sadar wisata ke masyarakat yang berada di sekitar objek wisata di kabupaten Lombok utara (KLU) agar wisatawan dapat terlayani dengan baik, Memperbaiki dan Melengkapi sarana dan prasarana pariwisata terutama objek wisata yang berada di wialayah sekitar objek wisata di kabupaten Lombok utara (KLU)

\section{Saran}

1. Pemerintah kabupaten lombok utara (KLU) melalui dinas pariwisata harus melakukan promosi secara komprehensip terutama promosi melalui media social, televisi dan memperbanyak brosur untuk memudahkan wisatawan dalam memperoleh informasi perjalanan wisata di kabupaten Lombok utara serta harus sering mengikuti event promosi yang ada di dalam dan luar negeri

2. Pemerintah kabupaten lombok utara (KLU) harus meningkatkan pelayanan kepa da wisatawan terutama sarana dan prasarana pariwisata agar wisatawan dapat terlayani dengan baik serta perlu adanya pelatihan-pelatihan kepariwisataan kepada pelaku pariwisata terutama masyarakat sekitar objek pariwisata sehingga akan dapat memberikan pelayanan kepada wisatawan. 


\section{DAFTAR PUSTAKA}

Anonin. Undang-Undang No. 10 Tahun 2009 Tentang Kepariwisataan

Begum \& Sarker. "Marketing Strategies For Tourism Industry In Bangladesh: Emphasize On Niche Market Strategy For Attracting Foreign Tourists", Journal of Arts, Science \& Commerce. .E-ISSN 2229-4686.ISSN 2231-4172. 2013

Gustavo. Marketing Management Trends in Tourism and Hospitality Industry: Facing the 21st Century Environment. International Journal of Marketing Studies; Vol. 5, No. 3; 2013,ISSN 1918-719X E-ISSN 1918-7203

Kotler,Philip.1997. Marketing Management, 9 Ed. Prentice-Hall, Inc. New York

Kuncoro,Mudrajad.2003. Metode Riset Untuk Ekonomi dan Bisnis.Erlangga.Jakarta

Marpaung, Happy. 2002. Pengetahuan Kepariwisataan. Alpabeta Bandung.

Magatep."The Impact of Tourism Marketing Mix Elements on the Satisfaction of Inbound Tourists to Jordan" International Journal of Business and Social Science . Vol. 6, No. 7; July 2015

Pitana, dkk. 2009. Pengantar Ilmu Pariwisata. CV Andi Offset: Yogyakarta

Pendit, Nyoman. 1999. Ilmu Pariwisata Sebuah Pengantar Perdana. PT. Pradnya Paramita. Jakarta

Purnomo (2009). Strategi Pemasaran Produk Wisata Minat Khusus Goa Cerme, Imogiri, Bantul”.Jurnal Karisma Vol.3(2): 99-112,2009

Rangkuti, Fredi. 2002. Analisis SWOT. Gramedia Pustaka Utama. Jakarta.

2006. Measuring Costumer Satisfaction. Edisi ketiga. Gramedia Pustaka Utama. Jakarta.

Suwantoro, Gamal, 1997. Dasar-dasar Pariwisata. ANDY. Yogyakarta

Spillane. James. 1994. Pariwisata Indonesia : Siasat Ekonomi dan Rekayasa Kebudayaan. Kanisius. Yogyakarta.

Sharpley. 1994. Tourism, Tourism and Socciety. Huntingdom: ELM Publication

Soekadijo, R. G, 1997. Anatomi Pariwisata : Memahami Pariwisata Sebagai Sistem Linkage. Gramedia Pustaka Utama. Jakarta.

Simamora, Bilson. 2008. Panduan Riset Perilaku Konsumen.Edisi Ketiga. Gramedia Pustaka Utama. Jakarta.

Umar,Husain.2001. Studi kelayakan Bisnis. Edisi 2, Jakarta : PT. Gramedia Pustaka Utama.Jakarta

2003. Business an Introduction. Gramedia Pustaka Utama. Jakarta

Vellas \& Becherel.1999.. The international marketing of travel and tourism,"Astrategic approach" Macmilan press 
154 | Irwan Suriadi,Didy Ika Supryadi/Marketing Strategy Pariwisata...

Wu \& Zhang. Research on the Tourism Effect and Marketing Strategy of Convention \& Exposition Industry: A Case Study of Shenzhen City of China. Journal of Service Science and Management, 2013, 6, 151-159

Yoeti, Oka,A 1997. Perencanaan dan Pengembangan Pariwisata. PT. Pradnya Paramita. Jakarta.

Yoeti, Oka, A. 2006. Pengantar Ilmu Pariwisata. Bandung, Angkasa. 